\title{
Downregulation of the constitutively expressed Hsc70 in diabetic myocardium is mediated by insulin deficiency
}

\author{
Harn-Shen Chen ${ }^{1,2}$, Jia Jia ${ }^{1}$, Hou-Fen Su${ }^{1}$, Hong-Da Lin ${ }^{2}$, Jaw-Wen Chen ${ }^{2}$, Shing-Jong Lin ${ }^{2}$, Jia-Ying Yang ${ }^{1}$, \\ Hui-Chin Lai ${ }^{1}$, Ruben Mestril ${ }^{3}$ and Ping $\mathbf{H}$ Wang ${ }^{1}$ \\ ${ }^{1}$ Department of Medicine, Biological Chemistry, Physiology and Biophysics, Center for Diabetes Research and Treatment, University of California, Irvine, \\ California 92697-4086, USA \\ ${ }^{2}$ Department of Medicine, Taipei Veterans General Hospital and Institute of Clinical Medicine, National Yang-Ming University, Taiwan \\ ${ }^{3}$ Department of Physiology, Loyola University, Chicago, Illinois 60153, USA \\ (Requests for offprints should be addressed to P H Wang; Email: phwang@uci.edu)
}

\begin{abstract}
The $70 \mathrm{kDa}$ heat shock protein family plays important cardiac protective roles against myocardial injuries. Reduced myocardial protection is a common feature of diabetic myocardium. This study was carried out to define the changes in the $70 \mathrm{kDa}$ heat shock protein family in the myocardium in the of streptozotocin-diabetes rats, and to explore the mechanisms through which diabetes alters the abundance of $\mathrm{Hsp} 70 / \mathrm{Hsc70}$ in cardiac muscle. In the diabetic myocardium, the abundance of $\mathrm{Hsc70}$ was significantly reduced. The abundance of Hsp70 was low in cardiac muscle and was not induced in the diabetic myocardium. Unlike Hsp60, Hsp70
\end{abstract}

and Hsc70 did not augment insulin-like growth factor-I receptor signaling in cardiac muscle cells. In cultured cardiomyocytes, insulin directly increased the abundance of Hsc70, whereas insulin could not modulate Hsp70. Treating diabetic rats with insulin restored myocardial $\mathrm{Hsc} 70$ level, but phlorizin treatment failed to restore myocardial $\mathrm{Hsc} 70$. These in vivo and in vitro studies showed that downregulation of Hsc70 in diabetic myocardium was secondary to insulin deficiency. Thus, insulin played a major role in maintaining adequate expression of $\mathrm{Hsc70}$ in cardiac muscle.

Journal of Endocrinology (2006) 190, 433-440

\section{Introduction}

Heat shock proteins play cardiac protective roles during myocardial injuries. The expression of various heat shock proteins typically increases upon myocardial stress (Latchman 2001, Lepore et al. 2001, Delogu et al. 2002, Cornelussen et al. 2003). For example, the expression of Hsp70 is dramatically induced after myocardial ischemic injuries (Trost et al. 1998, Lepore et al. 2001). The $70 \mathrm{kDa}$ family of heat shock proteins is involved in cellular protection during stress in various tissues (Erbse et al. 2004). Two isoforms of $70 \mathrm{kDa}$ heat shock proteins, Hsp70 and Hsc70, exist in mammalian tissues (Garrido et al. 2003, Erbse et al. 2004, Giffard \& Yenari 2004). Previous reports in the literature indicate that $\mathrm{Hsc70}$ is constitutively expressed and only mildly induced during stress situations, while Hsp70 is highly inducible upon stress stimuli (Erbse et al. 2004, Giffard \& Yenari 2004). Both Hsp70 and Hsc70 are capable of protecting cardiac muscle cells against injuries (Chong et al. 1998, Trost et al. 1998). Induction of Hsp70 is part of the defence mechanisms and may contribute to enhancement of myocardial protection during ischemic injury, as overexpressing Hsp70 in myocardium is associated with lesser ischemic myocardial damages (Mestril et al. 1996, Jayakumar et al. 2001). Despite the fact that the cardiac protective effects of $70 \mathrm{kDa}$ heat shock proteins have been well documented (Mestril et al. 1996, Jayakumar et al. 2001, Latchman 2001), little is known about the comparative expression of $\mathrm{Hsp} 70$ and $\mathrm{Hsc} 70$ in the diabetic state.

Diabetic myocardium is associated with reduced myocardial protection, and myocardial injuries are exacerbated in diabetic patients (Shan et al. 2003). Our recent study has shown reduced Hsp60 in diabetic myocardium (Shan et al. 2003). The goals of this study were to define the changes in Hsp70 and Hsc70 in diabetic myocardium and to study how diabetes alters the abundance of $\mathrm{Hsp} 70 / \mathrm{Hsc} 70$ in cardiac muscle. The results showed that the abundance of $\mathrm{Hsc} 70$ was significantly reduced in diabetic myocardium because of insulin deficiency. The abundance of $\mathrm{Hsp} 70$ is quite low in myocardium in vivo and was not induced by diabetes. In cultured cardiomyocytes, insulin increased the expression of $\mathrm{Hsc} 70$, whereas insulin had no effect on Hsp70. These findings provide new insight into how diabetes modulates $70 \mathrm{kDa}$ heat shock protein family.

\section{Materials and Methods}

\section{Materials}

Mouse anti-Hsp70 and anti-Hsc70 monoclonal antibodies were purchased from StressGen Biotechnologies Corp. 
(Victoria, BC, Canada). Other antibodies were from Santa Cruz Biolabs (Santa Cruz, CA, USA). Protein A/G PlusAgarose beads were from Santa Cruz Biolabs. Insulin-like growth factor-I (IGF-I) was from GroPep (Adelaide, Australia). Other chemicals were purchased from Sigma or Fisher Scientific (Pittsburgh, PA, USA).

\section{Animal model of diabetes}

Streptozotocin (STZ)-induced diabetes was obtained by injecting STZ $(80 \mathrm{mg} / \mathrm{kg}$ body weight, i.p. injection) into adult male Sprague-Dawley rats. The blood glucose levels were monitored by tail vein sampling. The diabetic rats were harvested at different intervals after the onset of diabetes (random glucose $>200 \mathrm{mg} / \mathrm{dl}$ ). When indicated, the diabetic rats were treated with ultralente insulin (3-9 units, s.c. twice a day) or phlorizin $(500 \mathrm{mg} / \mathrm{kg}$ per day) to normalize blood glucose. The animal experimental protocol was approved by the Institutional Animal Care and Utilization Committee at University of California, Irvine, CA.

\section{Neonatal cardiomyocytes culture}

Primary cultures of neonatal cardiomyocytes were prepared from Sprague-Dawley rats according to a protocol we previously described (Shan et al. 2003). Cardiomyocytes were plated in $100 \mathrm{~mm}$ Petri dishes and incubated at $37^{\circ} \mathrm{C}, 5 \% \mathrm{CO}_{2}$. When indicated, after overnight serum deprivation, cardiomyocytes were incubated with increasing concentrations of insulin $(0-1.0 \mathrm{mU} / \mathrm{ml})$, D-glucose $(200-1000 \mathrm{mg} / \mathrm{dl})$ or D-mannitol $(0-800 \mathrm{mg} / \mathrm{dl})$. Primary cardiomyocytes could not be grown at $<180 \mathrm{mg} / \mathrm{dl}$ of glucose, thus D-glucose concentration in our study was at least $200 \mathrm{mg} / \mathrm{dl}$.

\section{Immunoblots}

The tissues and cells were lysed with lysis buffer $(137 \mathrm{mM}$ $\mathrm{NaCl}, 20 \mathrm{mM}$ Tris- $\mathrm{HCl}, \mathrm{pH} 7 \cdot 5,10 \%$ glycerol, $1 \%$ Triton X-100 (Sigma), 0·5\% Nonidet P-40 (Sigma), 2 mM EDTA, $\mathrm{pH} 8 \cdot 0,3 \mu \mathrm{g} / \mathrm{ml}$ aprotinin, $3 \mu \mathrm{g} / \mathrm{ml}$ leupeptin, $2 \mathrm{mM}$ phenylmethylsulfonyl fluoride, $20 \mathrm{mM} \mathrm{NaF}, 10 \mathrm{mM} \mathrm{NaPP}$, and $2 \mathrm{mM} \mathrm{Na}_{3} \mathrm{VO}_{4}$ ). Equal amounts of proteins from each sample were separated by SDS-PAGE and then transferred to polyvinylidene difluoride membrane and incubated with a blocking buffer ( $3 \%$ BSA in $20 \mathrm{mM}$ Tris- $\mathrm{HCl}, \mathrm{pH} 7 \cdot 5$, $137 \mathrm{mM} \mathrm{NaCl}, 0 \cdot 1 \%$ Tween 20) for $1 \mathrm{~h}$ at room temperature. The membranes were sequentially incubated with primary antibodies overnight at $4{ }^{\circ} \mathrm{C}$, washed two times $(20 \mathrm{mM}$ Tris- $\mathrm{HCl}, \mathrm{pH} 7 \cdot 5,137 \mathrm{mM} \mathrm{NaCl}$, and $0 \cdot 1 \%$ Tween 20), incubated with horseradish peroxidase-conjugated secondary antibodies (1:7500-1:13000 dilution) for $1 \mathrm{~h}$ at room temperature, washed three times, and then detected with enhanced chemiluminescence (ECL). ECL was exposed with signals that were below saturation. All the comparisons were made with samples run on the same gel and exposed on the same film. For final analysis, the intensity of signals was normalized to the control sample on the same gel.

\section{Adenoviral vectors}

The construction of recombinant adenoviruses expressing Hsp70, Hsc70, and the control adenovirus Ad-SR was described previously (Mestril et al. 1996). The rat Hsp70 or $\mathrm{Hsc} 70$ gene was inserted into the $\mathrm{E} 1$ region of the Ad5 vector. $\mathrm{Hsp} 70$ or Hsc70 was cloned into the multiple cloning site of the adenoviral shuttle plasmid pACCMVpLpASR. The plasmid was co-transfected with pJM17 in 293 cells to generate Ad-Hsp70 and Ad-Hsc70. The viruses were replicated in 293 cells, purified by Virakit from Virapau (Carlsbad, CA, USA) and the viral titers were determined by plaque assay in 293 cells. Cardiomyocytes were plated in $100 \mathrm{~mm}$ Petri dishes in high-glucose Dulbecco's modified Eagle medium containing 10\% Fetal bovine serum and 1\% penicillin/streptomycin. When indicated, the cells were infected with adenoviruses of Ad-SR, Ad-Hsp70, or Ad-Hsc70 and incubated for $36-48 \mathrm{~h}$ at $37^{\circ} \mathrm{C}, 5 \% \mathrm{CO}_{2}$.

\section{Statistical analysis}

The data were expressed as mean \pm s.E. based on data derived from three to six independent experiments. The intensity of bands from Western blots were scanned with densitometry and digitally analyzed. Statistical significance was tested by Student's $t$-test or ANOVA with post hoc analysis when appropriate. A $P$-value below $0 \cdot 05$ was considered statistically significant.

\section{Results}

\section{Changes in $\mathrm{Hsp} 70$ and $\mathrm{Hsc70}$ in diabetic myocardium}

The first series of experiments were to characterize the changes in the $70 \mathrm{kDa}$ heat shock protein family, $\mathrm{Hsc} 70$ and Hsp70, in diabetic myocardium. Sprague-Dawley rats were injected with STZ or vehicle (plasma glucose $101 \pm 8$ vs $366 \pm 34 \mathrm{mg} / \mathrm{dl}, P<0 \cdot 001)$ and diabetic myocardium was harvested at the indicated time intervals. The abundance of myocardial Hsp70 and Hsc70 was analyzed with Western blots as shown in Fig. 1. Interestingly, the expression of $\mathrm{Hsc} 70$ was significantly reduced in myocardium after the onset of diabetes. Although the expression of inducible Hsp70 can be detected in cultured cardiomyocytes, the expression of $\mathrm{Hsp} 70$ is low in adult myocardium and there was no visible difference between the control and diabetic myocardium. These results indicate that there was a time-dependent downregulation of Hsc70 in diabetic myocardium, but there was no clear upregulation of $\mathrm{Hsp} 70$ in diabetic myocardium.

\section{Hsp 70 and Hsc70 did not modulate IGF-I receptor signaling}

In the diabetic myocardium, there was downregulation of IGF-I receptor as we had expected (Fig. 1). Recent studies in 
(A)

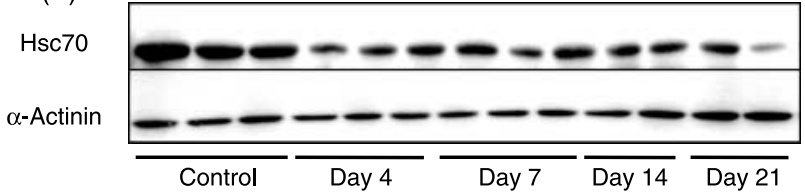

(B)

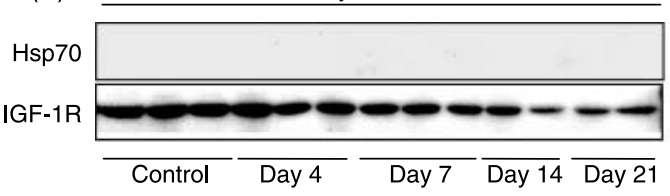

Myocytes

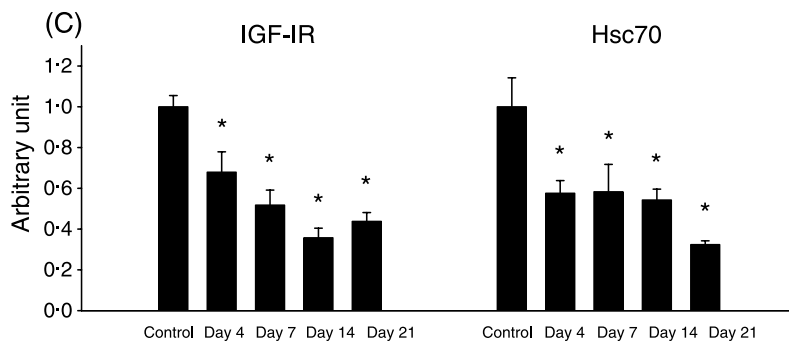

Figure 1 Changes in $70 \mathrm{kDa}$ heat shock proteins in diabetic myocardium. (A) The abundance of Hsc70 in streptozotocin-induced diabetic rat (STZ-DM) myocardium. Myocardium was harvested from control and diabetic rats and myocardial proteins were immunoblotted for Hsc70. Immunoblotting with $\boldsymbol{\alpha}$-actinin served as controls. (B) Immunoblotting of Hsp70 in control and STZ-DM myocardium. No visible Hsp70 proteins can be detected in normal or diabetic myocardium. Immunoblot of Hsc70 in cultured neonatal cardiomyocytes served as positive control. IGF-I receptor protein (IGF-IR) was visibly detected in the myocardium. (C) Time-course effects of diabetes on myocardial Hsc70 and IGF-I receptor. Each bar represents the mean \pm S.E. summarized from multiple experiments $(n=6-8$ animals in each group). The abundance of heat shock protein was normalized to the abundance of $\alpha$-actinin in each sample. ${ }^{*} P<0 \cdot 05$ vs the controls.

our laboratory have shown that Hsp60 modulated the abundance of myocardial IGF-I receptor and thus augmented IGF-I receptor signaling in cardiac muscle cells (Shan et al. 2003). Therefore, the next series of experiments were to investigate whether $70 \mathrm{kDa}$ heat shock protein can modulate IGF-I receptor signaling in primary cardiomyocytes. To this end, the cardiomyocytes were infected with adenoviral vector carrying Hsp70 (Fig. 2). Compared with the cells infected
(A)

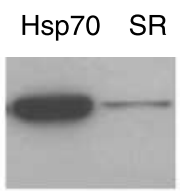

(B)
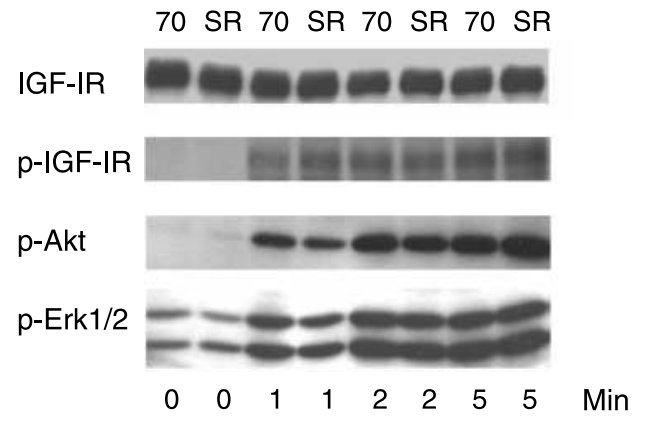

(C)
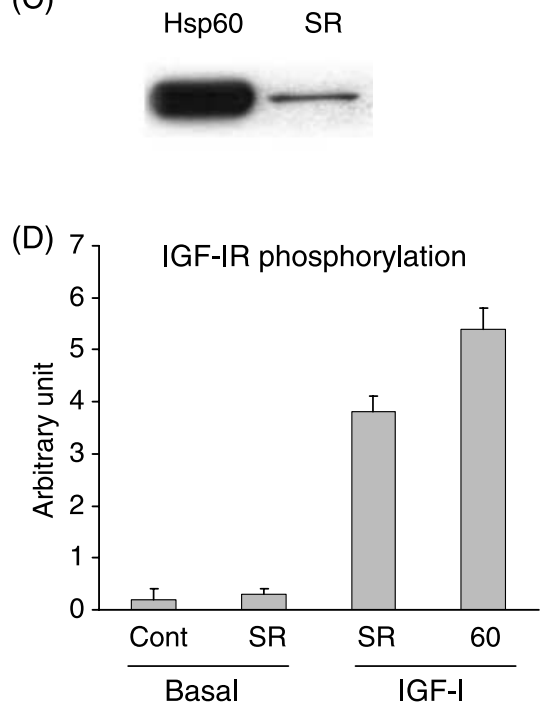

Figure 2 Overexpression of Hsp70 did not alter IGF-I receptor signaling in cardiomyocytes. Cardiomyocytes were infected with Ad-Hsp70 (70) or control virus Ad-SR (SR) (A), serum-deprived overnight, and then treated with IGF-I $\left(10^{-8} \mathrm{M}\right)$ for 1 , 2, or 5 min. (B) Phosphorylation of IGF-I receptor (p-IGF-IR), Akt (p-Akt), and Erk (p-Erk1/2). IGF-I receptor phosphorylation was studied by sequential immunoprecipitation (anti IGF-I receptor antibodies and protein A/G plus) and immunoblotting (anti-phosphotyrosine antibodies). The abundance of IGF-IR was determined by immunoblotting with antibodies against IGF-IR $\beta$-subunits. Phosphorylation of Akt and Erk was determined by immunoblotting with phosphor-specific antibodies. (C \& D) Positive controls were carried out in cardiomyocytes transduced with Ad-Hsp60 (60), which augmented IGF-I receptor signaling. Cont, control. 
with control virus, expression of $70 \mathrm{kDa}$ heat shock protein increased significantly in the cells transduced with Ad-Hsp70 (Fig. 2A). Overexpression of Hsp70 protein did not alter basal IGF-I receptor phosphorylation, Akt, or Erk. Upon IGF-I stimulation, receptor phosphorylation, Akt activation, and Erk activation were identical in the cells infected with Ad-SR and Ad-Hsp70 (Fig. 2B). In contrast, overexpression of Hsp60 lead to increased IGF-I receptor phosphorylation (Fig. 2C and D) as we previously reported (Shan et al. 2003). We also studied the effect of Hsc70 overexpression on IGF-I receptor signaling in cardiomyocytes. As shown in Fig. 3, IGF-I activation of IGF-I receptor, Erk, and Akt was not modulated by overexpression of Hsc70. These data suggested that, unlike $60 \mathrm{kDa}$ heat shock protein, $70 \mathrm{kDa}$ heat shock proteins do not modulate IGF-I receptor signaling in cardiac muscle.

(A)

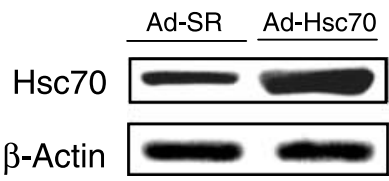

(B)
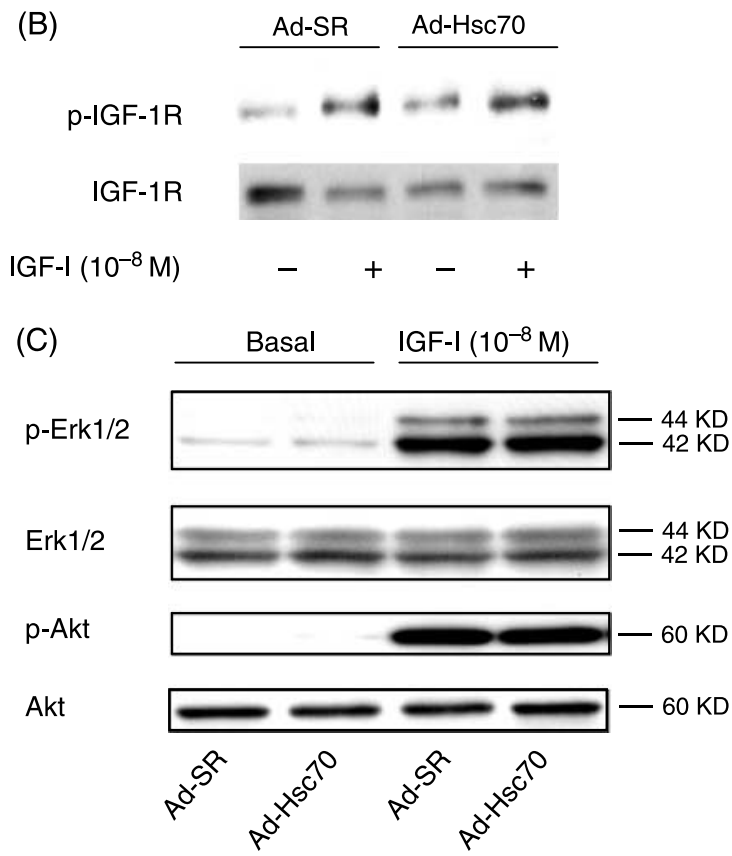

Figure 3 Overexpression of $\mathrm{Hsc} 70$ did not alter IGF-I signaling in cardiomyocytes. (A) Cardiomyocytes were infected with Ad-Hsc70 or control virus (Ad-SR), and Hsc70 expression was significantly increased in the cells infected with Ad-Hsc70. (B) Overexpression of Hsc70 did not alter phosphorylation of IGF-I receptor (p-IGF-IR) in cardiomyocytes. (C) Cardiomyocytes were serum-deprived overnight, and then treated with IGF-I $\left(10^{-8} \mathrm{M}\right)$ for 5 min for detection of Akt and Erk activation. Phosphorylation of Akt and Erk was analyzed by immunoblotting with anti-phosphoAkt or antiphosphoErk antibodies. Overexpression of Hsc70 did not alter IGF-I activation of Erk1/2 and Akt.
Independent effects of insulin on cardiac $\mathrm{Hsc} 70$ and $\mathrm{Hsp} 70$ in vitro

In order to investigate the independent effect of insulin and hyperglycemia on $70 \mathrm{kDa}$ heat shock protein, cardiomyocytes were incubated with increasing concentrations of insulin or D-glucose and the cells were harvested for immunoblotting with specific antibodies. Insulin increased the abundance of $\mathrm{Hsc70}$ in neonatal cardiomyocytes. However, Hsp70 proteins could not be induced by insulin (Fig. 4A and B). Hyperglycemia increased the expression of Hsp70, but not the expression of Hsc70 (Fig. 4C and D). The effect of D-glucose on Hsp70 expression was most significant at extremely high concentrations. D-Mannitol also induced a dose-dependent increase in Hsp70 (Fig. 4E and F), suggesting higher osmolality could induce Hsp70 in cardiomyocytes. D-Mannitol hyperosmolality did not alter the expression of $\mathrm{Hsc70}$ in cardiomyocytes (Fig. 4F).

The effect of insulin and phlorizin treatment on myocardial $\mathrm{Hsc} 70$ in vivo

To dissect further the independent effect of insulin deficiency and hyperglycemia in vivo on myocardial $70 \mathrm{kDa}$ heat shock proteins, we treated the diabetic animals with either insulin or phlorizin to normalize blood glucose. Phlorizin inhibits sodium-glucose co-transporter in renal tubule, promotes glucosuria, and normalizes blood glucose levels in diabetic animals (Laybutt et al. 2002). Body weight was restored and blood glucose was normalized in insulin treated rats, while in the phlorizin-treated animals only blood glucose was restored (Table 1). The abundance of myocardial $\mathrm{Hsc} 70$ was normalized after insulin therapy in diabetic rats, but phlorizin treatment failed to restore $\mathrm{Hsc70}$ content in diabetic myocardium (Fig. 5). These data provide in vivo evidence that insulin deficiency is the key factor leading to downregulation of myocardial $\mathrm{Hsc70}$ in diabetic myocardium. Hyperglycemia does not appear to be an important factor contributing to the regulation of myocardial $\mathrm{Hsc70}$ in vivo in the ranges of hyperglycemia seen in these diabetic rats. Furthermore, these data indicate that it is possible to normalize $\mathrm{Hsc} 70$ level in diabetic myocardium.

Changes in Hsp 70 and Hsc70 in kidney, adipose tissue, and skeletal muscle

In order to determine whether diabetes altered $70 \mathrm{kDa}$ heat shock protein in other tissues, various tissues were isolated from diabetic and control rats, homogenated, and immunoblotted with specific antibodies (Fig. 6). In the kidney, Hsc70 was increased in the diabetic rats. Insulin treatment normalized kidney Hsc70 levels; phlorizin treatment also corrected kidney Hsc70 levels. In the adipose tissue, Hsc70 is mildly increased in the diabetic rats, insulin treatment normalized Hsc70 levels and phlorizin therapy partially corrected this defect. Skeletal muscle Hsc70 was 
(A)

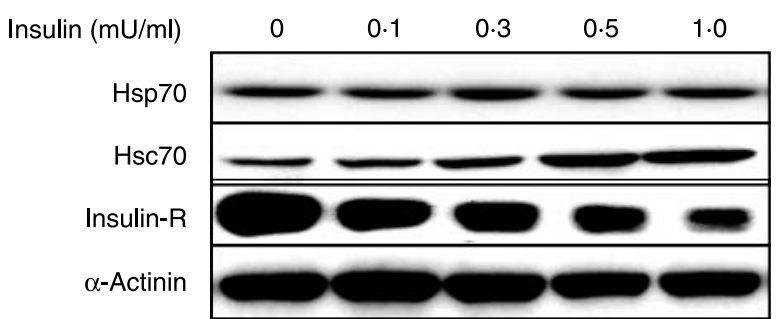

(C)

D-Glucose (mg/dl)

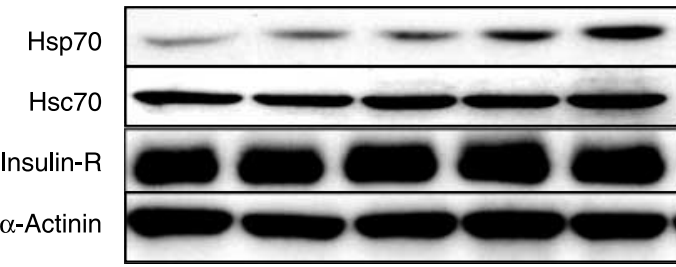

$(\mathrm{E})$

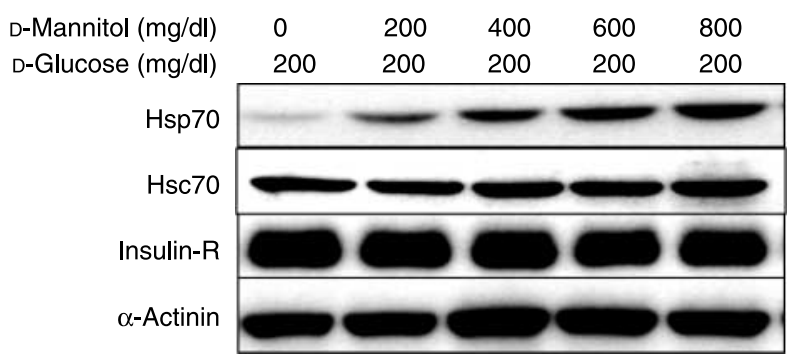

(B)

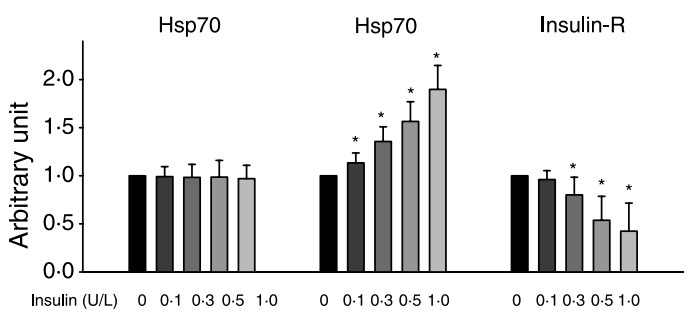

(D)

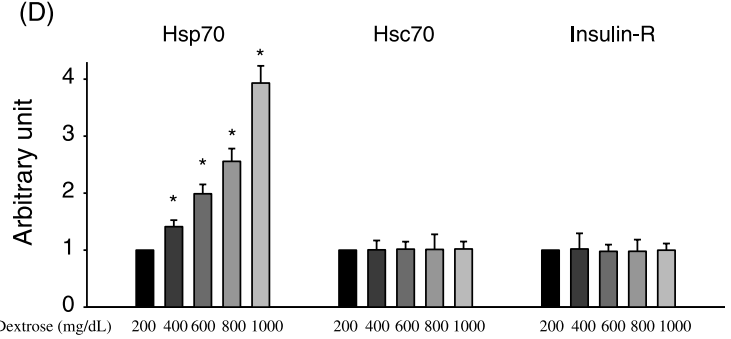

(F)

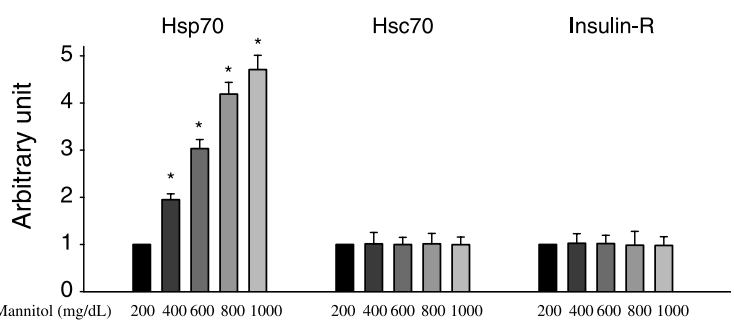

Figure 4 Independent effect of insulin and hyperglycemia on $70 \mathrm{kDa}$ heat shock proteins in cardiomyocytes. (A) The effect of insulin on Hsp70 and Hsc70. After overnight serum deprivation, cardiomyocytes were incubated with various concentrations of insulin or vehicles for $24 \mathrm{~h}$. Cell lysates were harvested and analyzed with immunoblots. (B) The effect of insulin on Hsp70 and Hsc70. Data represent results summarized from multiple experiments. The abundance of heat shock protein was normalized to the abundance of $\alpha$ actinin in each sample. (C) The effect of D-glucose on Hsp70 and Hsc70. Cardiomyocytes were incubated with various concentrations of D-glucose in growth medium for $24 \mathrm{~h}$. Cell lysates were harvested and analyzed with immunoblots. Primary cardiomyocytes could not be grown well at $<180 \mathrm{mg} / \mathrm{dl}$ of glucose, thus glucose concentration started at $200 \mathrm{mg} / \mathrm{dl}$. (D) Effect of hyperglycemia on Hsp70 and Hsc70 in vitro. Bar graph represents densitometry analysis from multiple experiments. The abundance of heat shock protein was normalized to the abundance of $\alpha$-actinin in each sample. (E) The effect of D-mannitol on Hsp70 and Hsc70. Cardiomyocytes were incubated with various concentrations of D-mannitol for $24 \mathrm{~h}$. Cardiomyocytes cannot be grown without glucose, therefore, $200 \mathrm{mg} / \mathrm{dl}$ D-glucose was present in the growth medium. (F) Effect of osmolality on $\mathrm{Hsp} 70$ and Hsc70. Bar graph represents densitometry analysis from multiple experiments. The abundance of heat shock protein was normalized to the abundance of $\alpha$-actinin in each sample.

Table 1 Characteristics of experimental animals. Diabetes was induced by streptozotocin injection (STZ-DM). Insulin or phlorizin were injected into subsets of diabetic rats to correct hyperglycemia

\begin{tabular}{|c|c|c|}
\hline & Body weight (g) & Blood glucose $(\mathrm{mg} / \mathrm{dl})$ \\
\hline Control & $262 \cdot 7 \pm 13 \cdot 1$ & $101 \cdot 8 \pm 6 \cdot 6$ \\
\hline STZ-DM & $227 \cdot 8 \pm 11 \cdot 6^{*}$ & $396 \cdot 2 \pm 35 \cdot 6^{*}$ \\
\hline Insulin-treated STZ-DM & $262 \cdot 8 \pm 26 \cdot 7 \dagger$ & $119 \cdot 7 \pm 11 \cdot 8+$ \\
\hline Phlorizin-treated STZ-DM & $236 \cdot 7 \pm 13 \cdot 0^{*}$ & $135 \cdot 2 \pm 28 \cdot 3+$ \\
\hline
\end{tabular}

Data represent means \pm s.E. $* P<0 \cdot 05$, vs controls. $+P<0 \cdot 05$, vs STZ-DM. 


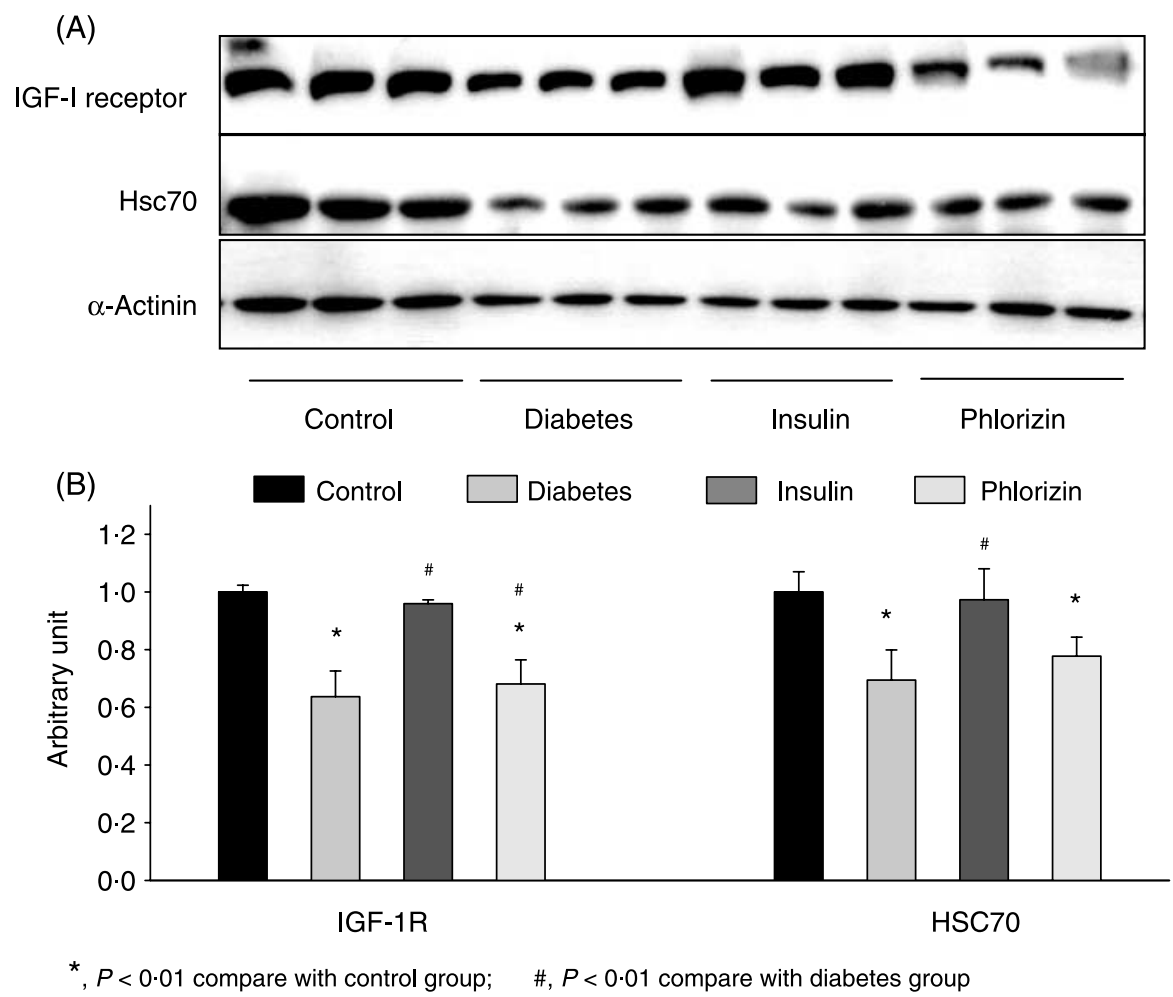

Figure 5 The effects of insulin and phlorizin on cardiac Hsc70 and IGF-I receptor in streptozotocininduced diabetic rat. When indicated, diabetic rats were treated with insulin or phlorizin for 6 days after the induction of diabetes. (A) Representative photo of myocardial Hsc70 and IGF-IR immunoblot. (B) Densitometry analysis of myocardial Hsc70 and IGF-IR. Bar graph represents densitometry analysis from multiple experiments ( $n=6-8$ animals in each group). The abundance of heat shock protein was normalized to the abundance of $\alpha$-actinin in each sample. Data represent means \pm s.E. ${ }^{*} P<0 \cdot 05$ vs controls; $+P<0 \cdot 05$ vs untreated diabetes.

downregulated in diabetic rats, similar to the changes in cardiac muscle. Insulin therapy completely restored $\mathrm{Hsc} 70$ levels in skeletal muscle, while phlorizin therapy partially increased Hsc70 levels in skeletal muscle. These experiments suggest that downregulation of $\mathrm{Hsc70}$ in skeletal muscle involved both insulin deficiency and hyperglycemia. In various diabetic tissues, the changes in Hsp60 generally paralleled the changes in IGF-I receptor (Arispe et al. 2002). The changes in Hsc70 did not necessarily parallel the changes in IGF-I receptor in each tissue investigated, which provide additional support to our in vitro observation that $70 \mathrm{kDa}$ heat shock proteins did not modulate IGF-I receptor protein (Figs 2 and 3).

\section{Discussion}

The expression of constitutive $\mathrm{Hsc} 70$ was reduced in diabetic myocardium, and the inducible $\mathrm{Hsp} 70$ was not induced in diabetic myocardium. Since these two heat shock proteins may protect cardiac muscle against injuries, these findings may have functional implications during the development of diabetic cardiomyopathy. Our data also indicate that insulin is a key factor in maintaining adequate constitutive expression of $\mathrm{Hsc70}$ in cardiac muscle. Insulin can directly induce the expression of $\mathrm{Hsc70}$ in cardiac muscle, which may contribute to the cardiac protective action of insulin.

The $70 \mathrm{kDa}$ family of heat shock proteins has two isoforms in mammalian cells. Hsc70 is a constitutively expressed $73 \mathrm{kDa}$ protein, and $\mathrm{Hsp} 70$ is a $72 \mathrm{kDa}$ protein that is inducible by stress (Garrido et al. 2003, Giffard \& Yenari 2004). These two isoforms share a high degree of sequence homology; both are composed of a $44 \mathrm{kDa}$ ATPase domain, a $18 \mathrm{kDa}$ peptide-binding domain, and a $10 \mathrm{kDa}$ C-terminal domain (Giffard \& Yenari 2004). Extensive evidence suggests both isoforms are involved in assisting protein folding, transporting protein across the membrane, regulating stress response, cooperating with other chaperone systems, and aiding cell survival. Despite the remarkable similarities in their structure and function, delicate differences exist between these two isoforms (Garrido et al. 2003, Giffard \& Yenari 2004). The subcellular localization is not entirely identical. Hsp70 has been found to bind the $40 \mathrm{~S}$ ribosomal subunit, whereas 

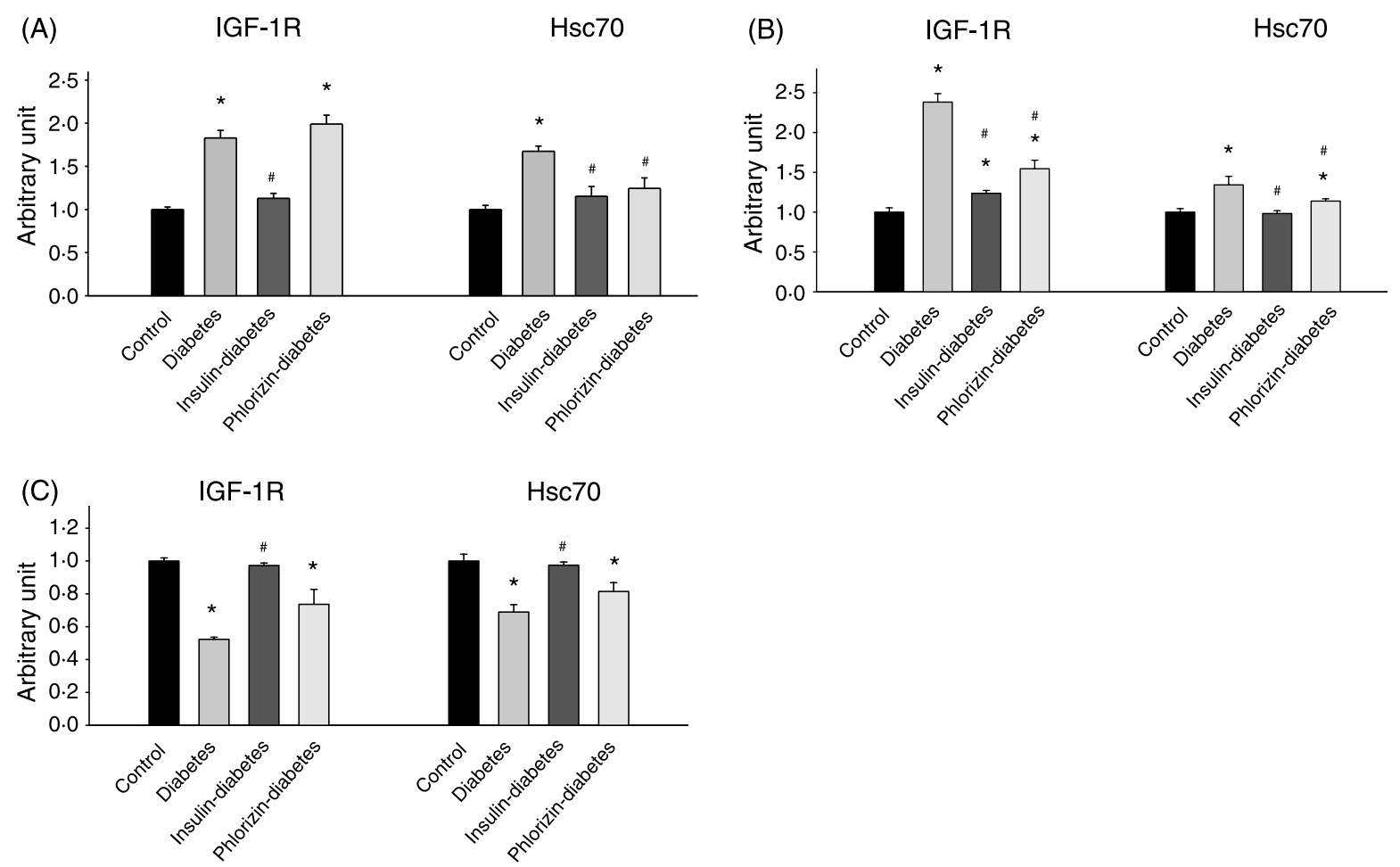

Figure 6 The abundance of Hsc70 and IGF-I receptor (IGF-R) in kidney, adipose tissue, and skeletal muscles of streptozotocin-induced diabetic rat. (A) The effects of insulin and phlorizin on kidney Hsc70 and IGF-I receptor. (B) The effects of insulin and phlorizin on adipose Hsc70 and IGF-I receptor. (C) The effects of insulin and phlorizin on skeletal muscle Hsc70 and IGF-I receptor. The abundance of heat shock protein was normalized to the abundance of $\alpha$-actinin in each sample. Bar graphs represent means \pm S.E., $n=6-8$ animals in each experimental group. $* P<0.05$ vs controls. $\# P<0.05$ vs diabetes.

Hsc70 can interact with nascent polypeptides in ribosomes (Beck \& De Maio 1994, Arispe et al. 2002). The functional significance of these dissimilarities is not yet known. A recent study by Atalay et al. (2004) showed that the levels of the inducible Hsp70 (Hsp72) were downregulated in the myocardium of STZ-induced diabetic rats. However, in our study, we did not detect a significant change in Hsp70/72 in myocardium. The abundance of Hsc70 was not investigated in the study by Atalay et al. (2004).

Current studies in the literature suggest that Hsp70 is the isoform that can be modulated in the mammalian myocardium. In the hypoxemic human and rabbit hearts, expression of the inducible Hsp70 was significantly increased, whereas Hsc70 expression was not affected (Rafiee et al. 2003). Similarly, induction of myocardial Hsp70 was found in rats receiving coronary artery ligation (Tanonaka et al. 2001), but the level of myocardial Hsc70 was not increased. In various tissues including the heart, the $70 \mathrm{kDa}$ heat shock protein family has a cell-protective function. Transgenic expression of Hsp70 reduced the size of myocardial infarction (Hutter et al. 1996). One of the key mechanisms through which $\mathrm{Hsp} 70$ and Hsc70 protect cells against injuries is through suppression of apoptosis signaling; overexpression of $\mathrm{Hsp} 70$ or Hsc70 leads to resistance against stress-induced caspase activation (Mosser et al. 2000, Giffard \& Yenari 2004). In cardiac muscle cells, overexpression of Hsc70 attenuated oxidative injuries and enhanced cell survival (Chong et al. 1998). Hsp70 has been found to inhibit apoptosis induced by tumor necrosis factor (TNF), oxidative stress, ceramide, and ultraviolet (UV) radiation (Giffard \& Yenari 2004). In addition to suppressing caspases, Hsp70 isoforms could antagonize apoptosis protease activating factor 1 and apoptosis inducing factor, modulate the Bcl2 family, and inhibit dephosphorylation of c-jun-N-terminal kinase (Giffard \& Yenari 2004).

We have recently reported that another heat shock protein, Hsp60, is capable of augmenting IGF-I receptor signaling in cardiac muscle cells (Shan et al. 2003). Unlike Hsp60, Hsp70 and $\mathrm{Hsc70}$ did not modulate IGF-I receptor signaling as shown in this study. We also observed that Hsp60 was reduced in diabetic myocardium (Shan et al. 2003). These observations indicate a milieu of heat shock protein downregulation in diabetic myocardium. Insulin deficiency is a likely culprit behind cardiac Hsp downregulation. Very little is known regarding the regulation of the Hsp70 family in diabetes. Many questions remain; for example, which signaling pathways do insulin receptors use to induce Hsc70 expression? How many heat shock protein families are affected by diabetes and insulin? Does downregulation of 
myocardial Hsc70 also occur in human diabetes? Does heat shock protein dysregulation ultimately lead to progression of diabetic cardiomyopathy? These questions are beyond the scope of this study but should be pursued in the future.

One caveat in our experimental models is the cell culture model used. Neonatal cardiomyocytes represent a reasonable in vitro model for cardiac muscle cells, but glucose metabolism and growth factor response can be different from adult cardiac muscle. Our in vivo and in vitro studies were in agreement regarding the effect of insulin on myocardial Hsc70 downregulation but there was a discrepancy between our in vitro and in vivo data regarding Hsp70 and hyperglycemia. In vitro studies showed that hyperglycemia increased Hsp70 in cultured cardiomyocytes; however, Hsp70 was not induced in diabetic myocardium. In cultured renal cells, hyperosmolality could induce Hsp70 expression (Cohen et al. 1991), but how osmolality regulates cardiac Hsp70 has not been investigated. It is not clear why $\mathrm{Hsp} 70$ was not induced in the diabetic myocardium. The complex in vivo biochemical changes in diabetic myocardium might have complicated the modulation of myocardial Hsp70.

Regulation of $\mathrm{Hsp} 70 / \mathrm{Hsc} 70$ appears to be complex in different tissues. The effect of diabetes, hyperglycemia, and insulin varies in the four tissues we have studied (Fig. 6). Reduced expression of Hsp70 has been found in the wound bed of diabetic $d b / d b$ mice (McMurtry et al. 1999), suggesting that delayed wound healing in diabetic animals may involve dysregulation of $\mathrm{Hsp} 70$. In the diabetes-prone $\mathrm{BB}$ rats, there was a lack of Hsp70 induction during beta cell destruction (Burkart et al. 2000). Specific mechanisms underlying differential regulation of $\mathrm{Hsc} 70$ in these tissues will require further research.

\section{Acknowledgements}

This work is supported by grants from National Heart, Lung and Blood Institute and National Institute of Diabetes and Digestive and Kidney Diseases (to $\mathrm{P} \mathrm{H} \mathrm{W).} \mathrm{The} \mathrm{authors}$ declare that there is no conflict of interest that would prejudice the impartiality of this scientific work.

\section{References}

Arispe N, Doh M \& De Maio A 2002 Lipid interaction differentiates the constitutive and stress-induced heat shock proteins Hsc70 and Hsp70. Cell Stress Chaperones 7 330-338.

Atalay M, Oksala NK, Laaksonen DE, Khanna S, Nakao C, Lappalainen J, Roy S, Hanninen O \& Sen CK 2004 Exercise training modulates heat shock protein response in diabetic rats. Journal of Applied Physiology 97 605-611.

Beck SC \& De Maio A 1994 Stabilization of protein synthesis in thermotolerant cells during heat shock. Association of heat shock protein72 with ribosomal subunits of polysomes. Journal of Biological Chemistry 269 21803-21811.

Burkart V, Liu H, Bellmann K, Wissing D, Jaattela M, Cavallo MG, Pozzilli P, Briviba K \& Kolb H 2000 Natural resistance of human beta cells toward nitric oxide is mediated by heat shock protein 70. Journal of Biological Chemistry 275 1-8.

Chong KY, Lai CC, Lille S, Chang C \& Su CY 1998 Stable overexpression of the constitutive form of heat shock protein 70 confers oxidative protection. Journal of Molecular and Cellular Cardiology 30 599-608.

Cohen DM, Wasserman JC \& Gullans SR 1991 Immediate early gene and HSP70 expression in hyperosmotic stress in MDCK cells. American Journal of Physiology 261 C594-C601.

Cornelussen RN, Vanagt WY, Prinzen FW \& Snoeckx LH 2003 Proteins involved in salvage of the myocardium. Advances in Experimental Medicine and Biology 543 277-291.

Delogu G, Signore M, Mechelli A \& Famularo G 2002 Heat shock proteins and their role in heart injury. Current Opinion in Critical Care 8 411-416.

Erbse A, Mayer MP \& Bukau B 2004 Mechanism of substrate recognition by Hsp70 chaperones. Biochemical Society Transactions 32 617-621.

Garrido C, Schmitt E, Cande C, Vahsen N, Parcellier A \& Kroemer G 2003 HSP27 and HSP70: potentially oncogenic apoptosis inhibitors. Cell Cycle $2579-584$.

Giffard RG \& Yenari MA 2004 Many mechanisms for hsp70 protection from cerebral ischemia. Journal of Neurosurgical Anesthesiology 16 53-61.

Hutter JJ, Mestril R, Tam EK, Sievers RE, Dillmann WH \& Wolfe CL 1996 Overexpression of heat shock protein 72 in transgenic mice decreases infarct size in vivo. Circulation 94 1408-1411.

JayakumarJ, Suzuki K, Sammut IA, Smolenski RT, Khan M, LatifN, Abunasra H, Murtuza B, Amrani M \& Yacoub MH 2001 Heat shock protein 70 gene transfection protects mitochondrial and ventricular function against ischemiareperfusion injury. Circulation 104(Suppl 1) I303-I307.

Latchman DS 2001 Heat shock proteins and cardiac protection. Cardiovascular Research 51 637-646.

Laybutt DR, Sharma A, Sgroi DC, Gaudet J, Bonner-Weir S \& Weir GC 2002 Genetic regulation of metabolic pathways in beta-cells disrupted by hyperglycemia. Journal of Biological Chemistry 277 10912-10921.

Lepore DA, Knight KR, Anderson RL \& Morrison WA 2001 Role of priming stresses and $\mathrm{Hsp} 70$ in protection from ischemia-reperfusion injury in cardiac and skeletal muscle. Cell Stress Chaperones 6 93-96.

McMurtry AL, Cho K, Young LJ, Nelson CF \& Greenhalgh DG 1999 Expression of HSP70 in healing wounds of diabetic and nondiabetic mice. Journal of Surgical Research 86 36-41.

Mestril R, Giordano FJ, Conde AG \& Dillmann WH 1996 Adenovirusmediated gene transfer of a heat shock protein 70 (hsp 70i) protects against simulated ischemia. Journal of Molecular and Cellular Cardiology 28 2351-2358.

Mosser DD, Caron AW, Bourget L, Meriin AB, Sherman MY, Morimoto RI \& Massie B 2000 The chaperone function of hsp70 is required for protection against stress-induced apoptosis. Molecular and Cellular Biology 20 7146-7159.

Rafiee P, Shi Y, Pritchard KA Jr, Ogawa H, Eis AL, Komorowski RA, Fitzpatrick CM, Tweddell JS, Litwin SB, Mussatto K et al. 2003 Cellular redistribution of inducible Hsp70 protein in the human and rabbit heart in response to the stress of chronic hypoxia: role of protein kinases. Journal of Biological Chemistry 278 43636-43644.

Shan Y, Yang T, Mestril R \& Wang PH 2003 HSP10 and HSP60 suppresses ubiquitination of IGF I receptor and augments IGF I receptor signaling in cardiac muscle - Implications on decreased myocardial protection in diabetic cardiomyopathy. Journal of Biological Chemistry 278 45492-45498.

Trost SU, Omens JH, Karlon WJ, Meyer M, Mestril R, Covell JW \& Dillmann WH 1998 Protection against myocardial dysfunction after a brief ischemic period in transgenic mice expressing inducible heat shock protein 70. Journal of Clinical Investigation 101 855-862.

Tanonaka K, Yoshida H, Toga W, Furuhama K \& Takeo S 2001 Myocardial heat shock proteins during the development of heart failure. Biochemical and Biophysical Research Communication 283 520-525.

Received in final form 9 March 2006

Accepted 11 April 2006

Made available online as an Accepted Preprint 10 May 2006 